GOSPODARKA SUROWCAMI MINERALNYMI - MINERAL RESOURCES MANAGEMENT

\title{
Analiza statystyczna parametrów mikrofacji dolomitu głównego w granicznej strefie platformy węglanowej
}

\section{Wprowadzenie}

Wieloletnie badania dolomitu głównego na Niżu Polskim dostarczyły dużej ilości wyników badań laboratoryjnych, zarówno standardowych, obejmujących przede wszystkim gęstość objętościową, porowatość efektywną oraz przepuszczalność fizyczną, jak i zaawansowanych, np. porozymetrii rtęciowej. Porozymetria okazała się źródłem nowych parametrów, które były podstawą zróżnicowania utworów dolomitu głównego w aspekcie różnorodnych mikrofacji oraz stref paleogeograficznych. Duża liczba wyników zapewniła poprawność statystyczną i wiarygodność analiz. Dalsze prognozy poszukiwawcze na platformie węglanowej niżu polskiego zapoczątkowały szczegółowe badania statystyczne z perspektywą wykorzystania wyników w przyszłości.

* Dr inż., AGH Akademia Górniczo-Hutnicza, Wydział Geologii Geofizyki i Ochrony Środowiska, Katedra Surowców Energetycznych, Kraków; e-mail: semyrka@agh.edu.pl

** Dr inż., *** Prof. dr hab. inż., AGH Akademia Górniczo-Hutnicza, Wydział Geologii Geofizyki i Ochrony Środowiska, Katedra Geofizyki, Kraków; e-mail: jarzyna@agh.edu.pl; krakow@agh.edu.pl 


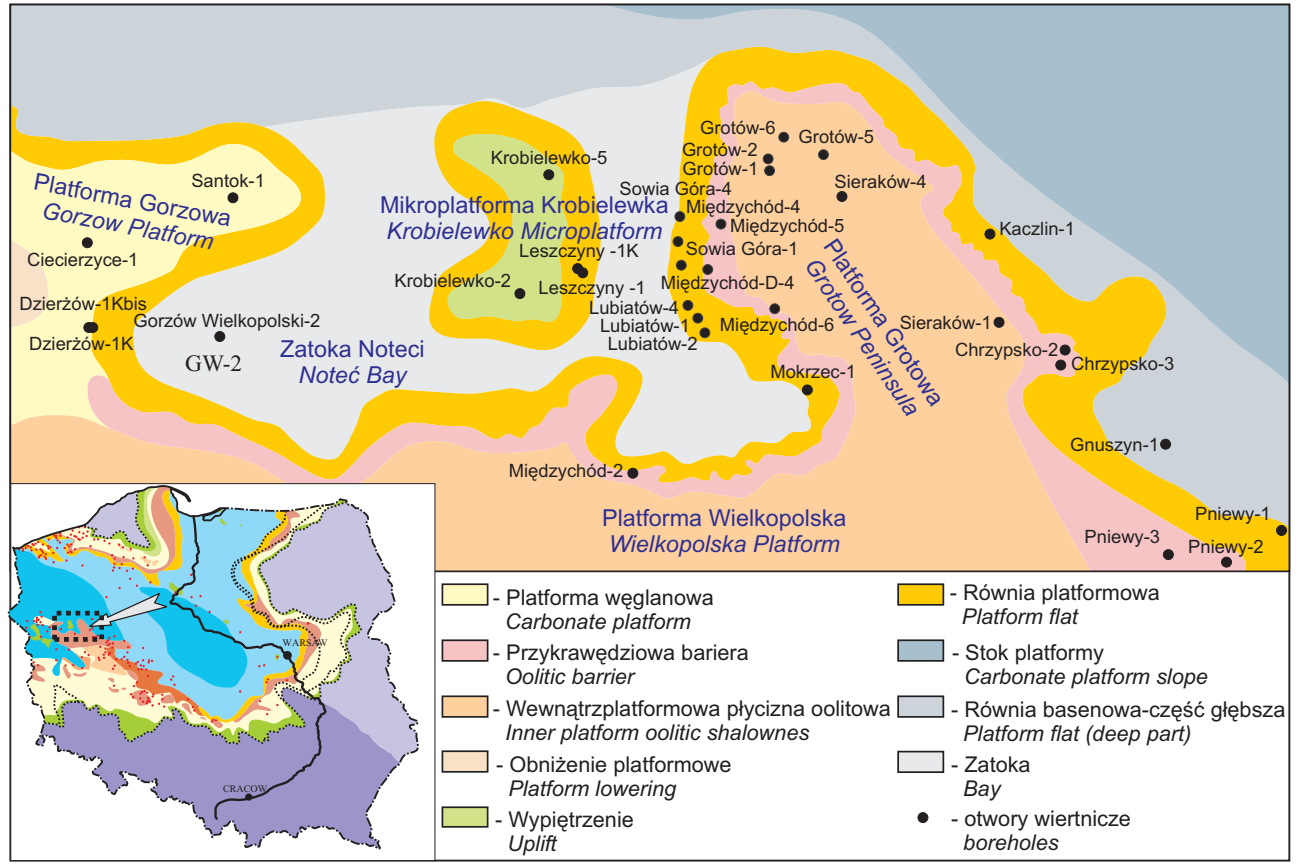

Rys. 1. Lokalizacja obszaru badań (Semyrka 2007, 2012)

Fig. 1. Location of study area (Semyrka 2007, 2012)

\section{Szkic budowy geologicznej obszaru badań}

Badania przeprowadzono we wschodniej części platformy Gorzowa, w zatoce Noteci wraz z mikroplatformą Krobielewka, na półwyspie Grotowa oraz na fragmencie platformy wielkopolskiej, sięgającym rejonu Pniew (rys. 1). Jest to perspektywiczny obszar, na którym w dolomicie głównym odkryto na przestrzeni ostatnich lat liczne złoża ropy naftowej i gazu ziemnego (Czekański i in. 2010).

Szczegółowa analiza danych geologicznych i geofizycznych, a w szczególności połączenie analiz mikrostrukturalnych i sedymentologicznych, pozwoliły na wydzielenie następujących środowisk depozycyjnych dolomitu głównego w omawianym obszarze: strefy podnóża platformy węglanowej, zbudowanej ze skłonowych mułów węglanowych o zróżnicowanej miąższości, redeponowanych utworów frakcji piaszczystej i żwirowej; strefy bariery węglanowej, gdzie obserwacje mikroskopowe pozwoliły na wydzielenie szerokiego spektrum odmian mikrofacjalnych. Wyróżniono m.in. wakstony peloidowe i peloidowo-bioklastyczne, pakstony i greinstony onkoidowo-ooidowe, pizoidowe, intraklastowe i intraklastowo-bioklastyczne, bandstony; strefy równi platformowej, gdzie analiza rdzeni, poparta szczegółowymi obserwacjami mikroskopowymi, pozwoliła na wyróżnienie wydzieleń mikrofacjalnych, reprezentowanych przez: bandstony, madstony, wakstony, pakstony, 
greinstony, flotstony, zbudowanych w różnych proporcjach z ooidów, onkoidów, intraklastów, peloidów i bioklastów.

Profil dolomitu głównego cechuje się zarówno miąższościowym jak i litologiczno-facjalnym zróżnicowaniem tych stref (rys. 2). W ich obrębie wyróżniono trzy podstawowe mikrofacje utworów: ziarnozwięzlych, czyli pakstonów, greinstonów, flotstonów i rudstonów; mułozwięzlych, czyli madstonów i wakstonów oraz mikrobialnych (bandstonów), obejmujących zarówno maty, jak i budowle mikrobialne. Wydzielone mikrofacje charakteryzują się nie tylko odmiennym rozwojem litologicznym, ale również zróżnicowanymi wielkościami parametrów petrofizycznych.

W badanych interwałach dolomitu głównego wyznaczono trzy mikrofacje (Semyrka 2013; Wagner, Kotarba, red. 2007; Jaworowski, Mikołajewski 2007): mikrofacje organogeniczną (1), obejmującą maty mikrobialne, algowe, tworzące bandstony, z powszechnie występującym mikrytem, mikrofację obejmującą utwory mułozwięzłe (2), tworzące madstony i pakstony z materią ilastą, niskoporowate, z możliwym mikrytem oraz mikrofację ziarnozwięzłą (3), utworzoną przez greinstony, z podrzędnie występującym mikrytem.

D-1K
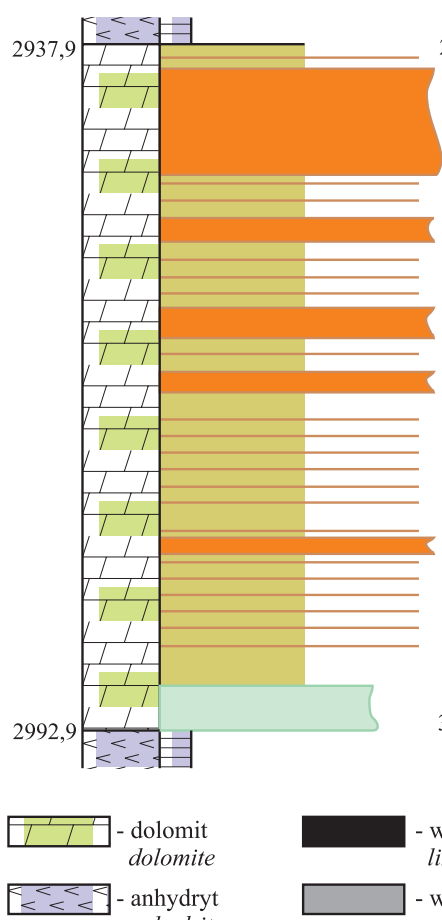

dolomit dolomite

anhydryt
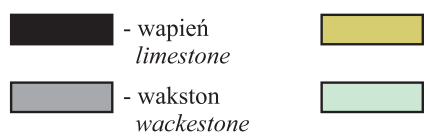

ziarnozwięzłe packstone/grainstone

- flotston/rudston floatstone/rudstone
L-1

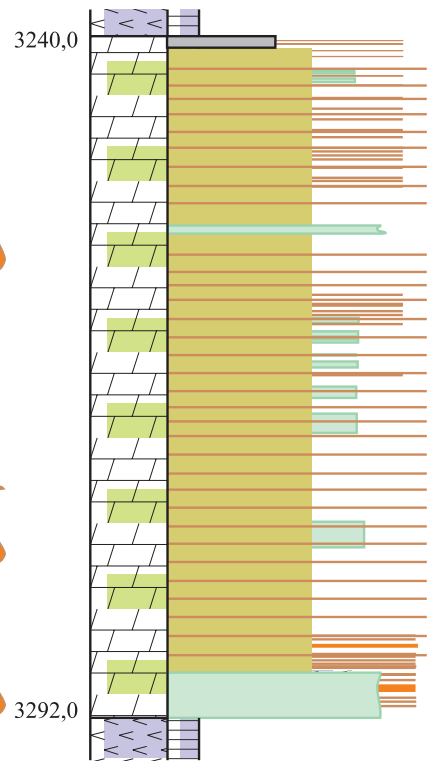
boundstone

biolaminacja biolamination

Rys. 2. Profil dolomitu głównego w otworach Dzierżów-1k, Ciecierzyce-1 i Lubiatów-1

(Mikołajewski i Buniak 2007, 2012)

Fig. 2. The Main Dolomite profile in Dzierżów-1k, Ciecierzyce-1 and Lubiatów-1 well (Mikołajewski i Buniak 2007, 2012) 
Mikrofacja ziarnozwięzła była najczęściej obserwowana w badanych interwałach dolomitu głównego.

\section{Analizy statystyczne danych}

Analizy statystyczne przeprowadzono na wynikach badań laboratoryjnych wykonanych na próbkach dolomitu głównego z otworów wiertniczych: Grotów-1, -2, -5, -6, Lubiatów-1, -2, -4, Międzychód-2, -4, -5, -6, Sieraków-1 i -4, Sowia Góra-1, -2k, -4, Ciecierzyce-1k, i -1, Dzierżów-1k i -1k bis, Santok-1, Chrzypsko-2 i -3, Gnuszyn-1, Gorzów Wielkopolski-2, Kaczlin-1, Krobielewko-2 i -5, Leszczyny-1 i -1k, Mokrzec-1, Pniewy-1, -2 i -3 (rys. 1). W wymienionych otworach nierównomiernie opróbowany profil dolomitu głównego obejmował zróżnicowane miąższości od 8,5 m, z głębokości 3237,0-3245,5 m w profilu otworu Leszczyny-1, do 87,5 m w profilu otworu Międzychód-5 z głębokości 3133,5-3221,0 m.

Całkowita liczba wyników porozymetrii rtęciowej wynosiła 543, natomiast helowej 2257 (tab. 1). Najliczniejszy zbiór stanowiły dane dotyczące mikrofacji ziarnozwięzłej (3) (407 próbek dla porozymetrii rtęciowej, 1614 - dla helowej), natomiast najmniej liczny był

Tabela 1. Liczba próbek w badaniach porozymetrii rtęciowej i helowej z podziałem na mikrofacje

Table 1. Number of samples in mercury and helium porosimetry with microfacies division

\begin{tabular}{|c|c|c|c|c|c|c|c|c|}
\hline \multirow{3}{*}{$\begin{array}{r}\text { Porozymetria } \\
\text { Nazwa otworu }\end{array}$} & \multicolumn{4}{|c|}{ Rtęciowa } & \multicolumn{4}{|c|}{ Helowa } \\
\hline & \multicolumn{8}{|c|}{ mikrofacja } \\
\hline & 1 & 2 & 3 & razem & 1 & 2 & 3 & razem \\
\hline Ilość próbek & 26 & 110 & 407 & 543 & 196 & 447 & 1614 & 2257 \\
\hline Sowia Góra-1 & 0 & 27 & 29 & 56 & 0 & 45 & 31 & 76 \\
\hline Sowia Góra-2k & 0 & 17 & 28 & 45 & 0 & 37 & 42 & 79 \\
\hline Sowia Góra-4 & 0 & 18 & 26 & 44 & 0 & 2 & 18 & 20 \\
\hline Lubiatów-1 & 1 & 10 & 34 & 45 & 2 & 18 & 79 & 99 \\
\hline Lubiatów-2 & 0 & 12 & 21 & 33 & 0 & 26 & 56 & 82 \\
\hline Lubiatów-4 & 0 & 17 & 23 & 40 & 0 & 36 & 27 & 63 \\
\hline Międzychód-4 & 2 & 3 & 32 & 37 & 9 & 6 & 130 & 145 \\
\hline Międzychód-5 & 2 & 0 & 25 & 27 & 13 & 1 & 151 & 165 \\
\hline Międzychód-6 & 4 & 3 & 10 & 17 & 19 & 25 & 49 & 93 \\
\hline Grotów-1 & 2 & 0 & 31 & 33 & 2 & 1 & 50 & 53 \\
\hline Grotów-2 & 4 & 0 & 36 & 40 & 6 & 7 & 39 & 52 \\
\hline Sieraków-1 & 4 & 3 & 49 & 56 & 5 & 5 & 87 & 97 \\
\hline
\end{tabular}


zbiór danych dotyczących mikrofacji organogenicznej (1) (26 próbek dla porozymetrii rtęciowej, 196 - dla helowej). Mikrofacja mułozwięzła znalazła się pośrodku, z reprezentacją w postaci 110 próbek badanych w porozymetrii rtęciowej i 447 - w porozymetrii helowej. W strefie równi platformowej występują otwory: Ciecierzyce-1k, Grotów-1 i -2, Santok-1 i Sieraków-1. Podnóże platformy węglanowej reprezentują otwory Sowia Góra-1, -2k i -4 oraz Lubiatów-1, -2 i -4. Strefę bariery węglanowej reprezentują dane z otworów Międzychód-4, -5 i -6 oraz Dzierżów-1k i -1k bis.

Analizowano wyniki porozymetrii rtęciowej, uzyskane w Katedrze Surowców Energetycznych WGGiOŚ AGH w Krakowie oraz helowej, uzyskane w Instytucie Nafty i Gazu w Krakowie. Przedmiotem badań były następujące parametry: przepuszczalność fizyczna, $\mathrm{K}[\mathrm{mD}]$, porowatość efektywna, Фef [\%], gęstość szkieletowa, $\rho \mathrm{m}\left[\mathrm{g} / \mathrm{cm}^{3}\right]$, gęstość objętościowa, $\rho b\left[\mathrm{~g} / \mathrm{cm}^{3}\right]$, średnia kapilara, $\mathrm{k} \_\mathrm{sr}[\mu \mathrm{m}]$, powierzchnia właściwa porów, $\mathrm{Sp}\left[\mathrm{m}^{2} / \mathrm{g}\right]$, średnica progowa $\mathrm{k} \_\mathrm{p}[\mu \mathrm{m}]$, udział porów o średnicach $>0,1 \mu \mathrm{m}, \mathrm{r} \_0,1[\%]$, porowatość dynamiczna dla gazu, (Фdyn.g) [\%], udział porów o średnicach $>1 \mu \mathrm{m}, \mathrm{r} \_1,0[\%]$, porowatość dynamiczna dla ropy, (Фdyn.r) [\%] (Burzewski i in. 2001; Bachleda-Curuś i in. 1997). Obliczono podstawowe statystyki oraz wielkości charakteryzujące rozkłady parametrów dla pełnego zbioru danych oraz dla podzbiorów charakteryzujących mikrofacje oraz poszczególne strefy paleogeograficzne. Szczegółowa geologiczna prezentacja materiału skalnego wykorzystanego do badań znalazła się we wcześniejszej pracy Romana Semyrki (Semyrka 2013), gdzie zamieszczono petrofizyczną charakterystykę subfacji dolomitu głównego w strefach paleogeograficznych na obszarze półwyspu Grotowa.

W tabeli 2 przedstawiono podstawowe statystyki gęstości objętościowej ( $\rho b)$ i szkieletowej ( $\rho \mathrm{m})$ oraz porowatości efektywnej (Фef), wyznaczonych na podstawie porozymetrii

Tabela 2. Podstawowe statystyki parametrów wyznaczonych na podstawie badań laboratoryjnych porozymetrii rtęciowej (wiersz w kolorze białym) i helowej (wiersz w kolorze szarym)

Table 2. Basic statistics of parameters determined from mercury (white line) and helium (grey line) porosimetry

\begin{tabular}{|c|c|c|c|c|c|c|c|c|c|c|c|c|c|}
\hline & $\mathrm{N}$ & śred. & med. & $\min$. & max. & $\mathrm{d} \mathrm{kw}$ & $\mathrm{g} \mathrm{kw}$ & p 10 & p 90 & war. & od. st. & sk. & kurt. \\
\hline \multirow{2}{*}{$\rho b$} & 543 & 2,40 & 2,40 & 1,64 & 2,92 & 2,27 & 2,57 & 2,11 & 2,68 & 0,05 & 0,22 & $-0,28$ & $-0,16$ \\
\hline & 2855 & 2,55 & 2,58 & 1,32 & 3,68 & 2,41 & 2,73 & 2,23 & 2,82 & 0,05 & 0,23 & $-0,59$ & 0,49 \\
\hline \multirow{2}{*}{$\rho \mathrm{m}$} & 543 & 2,76 & 2,78 & 2,16 & 3,01 & 2,71 & 2,82 & 2,65 & 2,85 & 0,01 & 0,10 & $-1,87$ & 6,42 \\
\hline & 2508 & 2,83 & 2,83 & 1,74 & 4,77 & 2,80 & 2,87 & 2,74 & 2,91 & 0,01 & 0,10 & 3,07 & 107,62 \\
\hline \multirow{2}{*}{$\Phi$ e } & 542 & 12,99 & 13,02 & 0,18 & 38,25 & 7,14 & 17,37 & 3,31 & 23,27 & 53,92 & 7,34 & 0,39 & $-0,19$ \\
\hline & 3383 & 9,09 & 7,37 & 0,00 & 33,01 & 2,98 & 13,6 & 1,17 & 20,00 & 52,61 & 7,25 & 0,87 & 0,04 \\
\hline
\end{tabular}

$\mathrm{N}$ - liczba danych, śred. - średnia arytmetyczna, med. - mediana, min. - wartość minimalna, max. - wartość maksymalna, d kw, g kw - kwartyl dolny i górny, p 10 i p 90 - percentyl 10 i 90\%, war. - wariancja, od. st. odchylenie standardowe, sk. - skośność, kurt. - kurtoza 
rtęciowej i helowej. Były to parametry powtarzające się w obu grupach pomiarów. Zaobserwowano rozbieżności w uzyskanych wartościach. W uzasadnieniu rozbieżności na pierwszym miejscu rozważono liczbę danych, w połączeniu z reprezentatywnością materiału użytego do badan. W przypadku porozymetrii rtęciowej liczba danych była wyraźnie mniejsza, niemniej istotna statystycznie. Mniejsza była także objętość materiału użytego do badania. W porozymetrii helowej używano próbek w kształcie walców (o średnicy $0,025 \mathrm{~m}$ i wysokości $0,029 \mathrm{~m}$ ), co wymagało wyboru twardszego fragmentu rdzenia. W porozymetrii rtęciowej wystarczające były okruchy skalne o objętości około $2 \mathrm{~cm}^{3}$. W ten sposób można uzasadnić wyższe średnie wartości gęstości objętościowej oraz niższe wartości porowatości efektywnej uzyskane w porozymetrii helowej. Wariancja i odchylenie standardowe, obserwowane na tym samym poziomie w obu grupach, wskazały na podobne zróżnicowanie danych w obu zbiorach. Niska wariancja i niskie odchylenie standardowe gęstości objętościowej informują że analizowane wartości są wyraźnie skupione wokół średniej. Wyższa wariancja i odchylenie standardowe porowatości efektywnej świadczą o większym zróżnicowaniu wartości w obu zbiorach danych. Podane wartości minimalne i maksymalne charakteryzują szerokość zbiorów danych, natomiast kwartyle podają wartości, poniżej których w przypadku dolnego znajduje się $25 \%$ danych ze zbioru, a w przypadku górnego $75 \%$ danych. W przypadku porowatości efektywnej (Фef) oznacza to, że 50\% danych przyjmuje wartości między 7,14 a 17,37\% dla zbioru danych z porozymetrii rtęciowej oraz 2,89 i $13,6 \%$ dla zbioru danych z porozymetrii helowej. Analiza percentyli w przypadku porowatości efektywnej w zbiorze danych porozymetrii rtęciowej wskazuje, że $90 \%$ wyników znajduje się w przedziale 3,31-23,27\%. Zatem, w obu zbiorach dominują wysokie wartości porowatości efektywnej.

Histogram gęstości objętościowej dla zbioru danych z porozymetrii rtęciowej porównano z rozkładem normalnym (rys. 3a). Współczynnik skośności rozkładu gęstości przyjął wartość ujemną, co świadczy o nieznacznym wydłużeniu lewej gałęzi rozkładu. Kurtoza również była ujemna, co wskazuje na bardziej spłaszczony rozkład w porównaniu do normalnego. Kurtoza, czyli współczynnik koncentracji, był potraktowany jako względna miara skupienia wartości gęstości objętościowej wokół średniej. Niewielka wartość kurtozy była zgodna z niewielką wariancją. Skupienie wartości gęstości objętościowej wokół średnich z obu pomiarów potwierdziły także oba kwartyle, dolny wskazujący na wartość gęstości, która wraz z niższymi wartościami stanowi $25 \%$ zbioru danych, oraz górny, który wskazuje na wartość, która z mniejszymi stanowi $75 \%$ danych. Obie te statystyki są bliskie średniej gęstości objętościowej, w obu grupach danych. Podobne wnioski wyciągnięto na podstawie wartości obu percentyli (10\% i $90 \%)$.

Podobnie zinterpretowano wartość skośności rozkładu gęstości objętościowej z porozymetrii helowej, gdzie ujemna wartość wskazała również na wydłużoną lewą gałąź rozkładu. Dodatnia kurtoza wskazała natomiast na bardziej smukły od normalnego rozkład gęstości objętościowej w tym przypadku. Taki wynik był zgodny z wyższą średnią wartością gęstości objętościowej z porozymetrii helowej. 
Histogram porowatości efektywnej z porozymetrii helowej (rys. 3b) wykazał skośność dodatnią, co wskazało na rozbudowaną prawą gałąź. Rozbudowana prawa gałąź oznacza większe zróżnicowanie ilości danych w wydzielonych klasach powyżej średniej wartości $(9,09 \%)$. Miał także dodatnią kurtozę, która wskazała na bardziej smukły rozkład w porównaniu do normalnego. Kształt histogramu na rysunku $3 \mathrm{~b}$ był potwierdzony wartościami porowatości efektywnej - średnią i maksymalną (tab. 2). Kurtoza była niewielka,

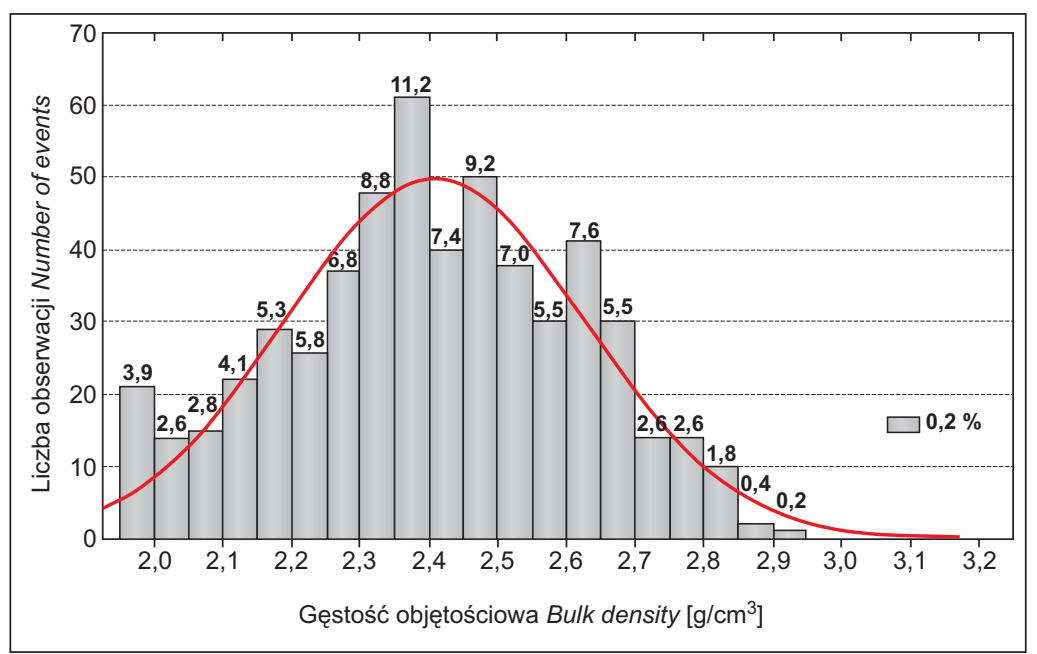

Rys. 3a. Histogram rozkładu gęstości objętościowej dolomitu głównego, porozymetria rtęciowa

Fig. 3a. Histogram of bulk density distribution from the Main Dolomite, mercury porosimetry

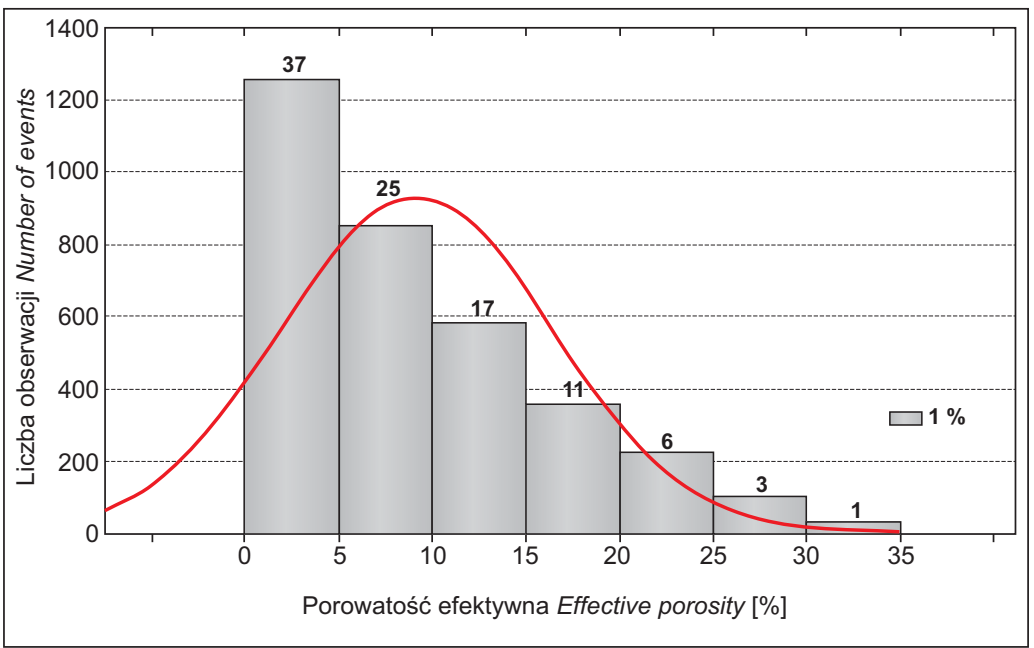

Rys. 3b. Histogram rozkładu porowatości efektywnej dolomitu głównego, porozymetria helowa

Fig. 3b. Histogram of effective porosity distribution from the Main Dolomite, helium porosimetry 
czyli koncentracja danych wokół średniej jest niewielka, o czym świadczy także duża wariancja i odchylenie standardowe. Wartości kwartyli i percentyli w przypadku porowatości efektywnej w obu grupach pomiarowych potwierdziły większe zróżnicowanie zbiorów danych.

\section{Omówienie wyników porozymetrii rtęciowej z uwzględnieniem podziału na mikrofacje}

Podstawowe statystyki pozostałych parametrów (tab. 3) posłużyły do charakterystyki zmienności zbiorów danych. W tabeli 3 zawarto, obok wyników dla pełnego zbioru danych (kolor czarny), także wyniki dla facji (3) utworów ziarnozwięzłych (kolor niebieski) oraz facji (2) utworów mułozwięzłych (kolor czerwony). Większość parametrów została wyznaczona na podstawie porozymetrii rtęciowej, a przepuszczalność fizyczna na podstawie standardowych pomiarów laboratoryjnych. W tabeli 3 występują tylko wybrane wielkości, które zostały wyznaczone na podstawie badań porozymetrycznych. Wartość średniej kapilary jest obliczona jako średnia arytmetyczna średnic badanych porów. Przy badaniach porozymetrycznych zakładano, że pory mają kształt cylindryczny. Promień porów (kapilar) obliczano na podstawie wzoru Washburna, przy znajomości ciśnienia, które spowodowało wejście rtęci do porów o danej średnicy. Średnica progowa definiowana była jako minimalna wartość średnicy kapilary, która umożliwiała wejście rtęci do skały. Powierzchnię właściwą materiału ziarnistego (skały) określano jako powierzchnię przypadającą na jednostkę masy. Procentowy udział porów o średnicach większych od $0,1 \mu \mathrm{m}$ jest związany z porowatością dynamiczną dla gazu, natomiast większych od $1 \mu \mathrm{m}-\mathrm{z}$ porowatością dynamiczną dla ropy. Porowatość dynamiczna jest synonimem porowatości efektywnej skał, ale jest odniesiona do zdefiniowanej fazy węglowodorowej - ropnej lub gazowej. Może również odnosić się do wód złożowych.

Najpierw poddano analizie pełny zbiór danych. Parametry przedstawione w tabeli 3 wykazały podobne charakterystyki. Trzy pierwsze wielkości, silnie związane ze sobą przez pomiar, wykazały podobne cechy statystyczne - średnią i medianę oddalone od siebie, średnią większą od mediany, co świadczyło o prawostronnym rozkładzie. Zaobserwowano także dodatnie wartości skośności, potwierdzające przedstawiony wniosek, i dodatnie kurtozy, wskazujące na smuklejsze, w stosunku do normalnego, rozkłady parametrów. Podobne cechy statystyczne wykazały także porowatość dynamiczna dla gazu i ropy oraz liczby porów o średnicach odpowiednio większych od 0,1 i $1 \mu \mathrm{m}$. Wartości średnich i median były podobne. Skośności i kurtozy były niewielkie. W przypadku porowatości dynamicznej dla gazu kurtoza była ujemna, co wskazało na minimalne spłaszczenie rozkładu w stosunku do normalnego. W przypadku liczby porów o średnicach większych o $1 \mu \mathrm{m}$ skośność i kurtoza były ujemne. Skośność była również ujemna w przypadku porów o średnicach większych od $0,1 \mu \mathrm{m}$. Liczby te wskazały na nieznacznie lepiej rozwiniętą lewą gałą́ rozkładu. Ekstremalnie wysokie wartości wariancji i odchylenia standardowego średnicy 
Tabela 3. Podstawowe statystyki parametrów wyznaczonych na podstawie badań laboratoryjnych uzyskanych dla pełnego zbioru danych dolomitu głównego (kolor czarny), mikrofacji 3 - utworów ziarnozwięzłych (kolor niebieski)

i mikrofacji 2 - utworów mułozwięzłych (kolor czerwony)

Table 3. Basic statistics of parameters determined from the laboratory measurements obtained for the total data set of the Main Dolomite (black colour),

microfacies 3 - grainstones (blue colour) and microfacies 2 - mudstones (red colour)

\begin{tabular}{|c|c|c|c|c|c|c|c|c|c|c|c|c|}
\hline & śred. & med. & $\min$. & $\max$ & $\mathrm{d} k w$ & $\mathrm{~g} \mathrm{kw}$ & p 10 & p 90 & war. & od. st. & sk. & kurt. \\
\hline \multirow{3}{*}{$\begin{array}{l}\text { k_sr } \\
{[\mu \mathrm{m}]}\end{array}$} & 1,08 & 0,53 & 0 & 27,20 & 0,21 & 12,00 & 0,06 & 2,33 & 4,40 & 2,09 & 7,27 & 74,50 \\
\hline & 1,20 & 0,58 & 0 & 27,21 & 0,30 & 1,19 & 0,09 & 2,65 & 5,13 & 2,26 & 7,14 & 69,74 \\
\hline & 0,41 & 0,19 & 0 & 1,68 & 0,09 & 0,78 & 0,02 & 1,26 & 0,24 & 0,49 & 1,32 & 0,61 \\
\hline \multirow{3}{*}{$\begin{array}{l}\mathrm{k} \_\mathrm{p} \\
{[\mu \mathrm{m}]}\end{array}$} & 9,42 & 3,00 & 0 & 100,20 & 1,00 & 10,00 & 0,40 & 30,00 & 223,72 & 14,96 & 2,94 & 10,48 \\
\hline & 10,23 & 3,00 & 0 & 100,20 & 1,00 & 12,00 & 0,60 & 30,00 & 252,44 & 15,89 & 2,82 & 9,52 \\
\hline & 9,40 & 1,50 & 0,10 & 70,00 & 0,60 & 5,50 & 0,10 & 40,00 & 330,74 & 18,19 & 2,44 & 5,44 \\
\hline \multirow{3}{*}{$\begin{array}{c}\mathrm{Sp} \\
{\left[\mathrm{m}^{2} / \mathrm{g}\right]}\end{array}$} & 0,53 & 0,39 & 0 & 6,63 & 0,17 & 0,65 & 0,09 & 0,96 & 0,37 & 0,61 & 4,35 & 28,89 \\
\hline & 0,50 & 0,40 & 0 & 6,63 & 0,20 & 0,62 & 0,09 & 0,87 & 0,32 & 0,57 & 5,65 & 46,67 \\
\hline & 0,70 & 0,66 & 0 & 2,10 & 0,46 & 0,87 & 0,02 & 1,56 & 0,25 & 0,50 & 1,03 & 1,52 \\
\hline \multirow{3}{*}{$\mathrm{r}_{-} 0,1 \mu \mathrm{m}$} & 89,29 & 98,00 & 0 & 100,00 & 93,00 & 100,00 & 60,00 & 100,00 & 412,24 & 20,30 & $-2,40$ & 4,87 \\
\hline & 92,48 & 98,00 & 8,00 & 100,00 & 95,00 & 100,00 & 80,00 & 100,00 & 291,24 & 17,26 & $-3,24$ & 9,96 \\
\hline & 79,04 & 91,00 & 10,00 & 100,00 & 67,00 & 98,00 & 23,00 & 100,00 & 709,64 & 26,64 & $-1,52$ & 1,38 \\
\hline \multirow{3}{*}{$\begin{array}{c}\text { Фdyn.g } \\
{[\%]}\end{array}$} & 12,34 & 12,80 & 0 & 36,37 & 6,03 & 17,02 & 1,61 & 22,64 & 58,49 & 7,65 & 0,30 & $-0,42$ \\
\hline & 14,16 & 14,50 & 0,11 & 36,00 & 9,54 & 18,88 & 3,39 & 23,81 & 52,98 & 7,28 & 0,03 & $-0,28$ \\
\hline & 9,48 & 6,42 & 0,29 & 36,37 & 4,38 & 14,80 & 0,60 & 20,67 & 80,43 & 8,97 & 1,51 & 2,37 \\
\hline \multirow{3}{*}{$\mathrm{r}_{-} 1,0 \mu \mathrm{m}$} & 50,85 & 54,50 & 2,00 & 100,00 & 18,00 & 80,00 & 8,00 & 91,00 & 989,70 & 31,46 & $-0,07$ & $-1,46$ \\
\hline & 51,33 & 55,00 & 2,00 & 100,00 & 18,00 & 82,00 & 8,00 & 91,00 & 1021,44 & 31,96 & $-0,11$ & $-1,49$ \\
\hline & 37,96 & 25,00 & 3,00 & 100,00 & 10,00 & 65,00 & 6,00 & 91,00 & 982,84 & 31,35 & 0,70 & $-0,92$ \\
\hline \multirow{3}{*}{$\begin{array}{c}\text { Фdyn.r } \\
{[\%]}\end{array}$} & 7,76 & 6,50 & 0 & 34,40 & 1,30 & 12,40 & 0,48 & 18,80 & 52,61 & 7,25 & 0,92 & 0,14 \\
\hline & 8,79 & 8,42 & 0 & 28,97 & 1,50 & 13,50 & 0,48 & 20,00 & 56,53 & 7,52 & 0,67 & $-0,43$ \\
\hline & 5,25 & 1,21 & 0,29 & 34,40 & 0,50 & 6,83 & 0,30 & 16,87 & 65,36 & 8,08 & 2,36 & 6,10 \\
\hline \multirow{3}{*}{$\mathrm{K}[\mathrm{mD}]$} & 3,31 & 0,01 & 0 & 500,00 & 0 & 0,40 & 0 & 3,96 & 493,02 & 22,20 & 15,20 & 281,62 \\
\hline & 4,19 & 0,03 & 0 & 500,00 & 0 & 0,74 & 0 & 5,20 & 664,74 & 25,78 & 13,35 & 213,70 \\
\hline & 1,25 & 0 & 0 & 148,83 & 0 & 0,06 & 0 & 0,81 & 115,89 & 10,76 & 13,39 & 184,09 \\
\hline
\end{tabular}

Oznaczenia jak w tabeli 2. 
progowej, porów o średnicach większych o $0,1 \mu \mathrm{m}$ oraz większych od $1 \mu \mathrm{m}$ wskazały na duży rozrzut tych wartości wokół średniej. Podobne cechy wykazała przepuszczalność fizyczna, co wyraźnie podkreśla związek tych parametrów, a także wskazuje na obecność szczelin.

Szczegółowa analiza wartości w tabeli 3 pozwoliła także na porównanie podstawowych statystyk parametrów wyznaczonych na podstawie badań laboratoryjnych dla wszystkich danych dolomitu głównego oraz dla utworów ziarnozwięzłych i mułozwięzłych. Dla wszystkich parametrów jest zachowany następujący układ: najwyższe wartości przyjmują parametry dla skał mikrofacji (3) (utworów ziarnozwięzłych), pośrednie - wartości policzone dla wszystkich danych, najniższe wartości - skały mikrofacji (2) (utworów mułozwięzłych). Większe różnice zaobserwowano między wartościami w całym zbiorze danych a wartościami charakterystycznymi dla utworów mułozwięzłych, w porównaniu do różnic między wartościami w całym zbiorze danych a wartościami charakterystycznymi dla utworów ziarnozwięzłych. Takie relacje potwierdzają stwierdzenie, że mikrofacja (3) utworów ziarnozwięzłych dominuje w badanej populacji próbek. Skośność, będąca miarą asymetrii rozkładu, okazała się ujemna dla rozkładów porów o średnicach większych od $0,1 \mu \mathrm{m}$ (w trzech grupach danych) oraz dla rozkładów porów o średnicach większych od $1 \mu \mathrm{m}$ (w grupie wszystkich danych i dla mikrofacji 3). Rozkład porów o średnicach większych od $1 \mu \mathrm{m}$ dla danych mikrofacji (2) charakteryzował się skośnością dodatnią. Ujemna skośność potwierdziła bardziej rozbudowaną lewą gałą́ rozkładu, czyli dominację i większe zróżnicowanie porów o bardzo małych średnicach. Kurtoza okazała się ujemna, a skupienie danych wokół średniej słabsze w przypadku porowatości dynamicznej dla gazu oraz w przypadku porowatości dynamicznej dla ropy, ale jedynie dla grupy danych mikrofacji (3). Wzajemne powiązanie analizowanych wielkości między sobą i możliwość wyznaczenia jednych na podstawie drugich były wyraźnie widoczne na podstawie współczynników korelacji wzajemnej (tab. 4 i 5).

W pełnym zbiorze danych wysokie współczynniki korelacji zaobserwowano między gęstością objętościową i porowatością efektywną w obu grupach danych (dla wyników porozymetrii rtęciowej $\mathrm{r}=-0,87$, a dla helowej $\mathrm{r}=-0,95$ ). Wysokie współczynniki korelacji wystąily również między porowatością efektywną a porowatością dynamiczną dla gazu $(\mathrm{r}=0,99)$ oraz dla ropy $(\mathrm{r}=0,81)$. Podobne relacje, ale przy znacznie niższych współczynnikach korelacji, wystąiły między porowatością efektywną a procentowym udziałem porów o średnicach większych od $0,1 \mu \mathrm{m}$, oraz udziałem porów o średnicach większych od $1 \mu \mathrm{m}$. Odpowiednie relacje między porowatością dynamiczną dla gazu (Фdyn.g) a liczbą porów o średnicach większych od $0,1 \mu \mathrm{m}\left(\mathrm{r} \_0,1\right)$ oraz porowatością dynamiczną dla ropy (Фdyn.r) a liczbą porów o średnicach większych od $1 \mu \mathrm{m}\left(\mathrm{r}_{-} 1,0\right)$ miały współczynniki korelacji wyższe i odpowiednio równe 0,59 i 0,78 . Relacje między średnią kapilarą, średnicą progową i powierzchnią właściwą a porowatością efektywną charakteryzowały się niewielkimi współczynnikami korelacji. Takie zależności pozostawały $\mathrm{w}$ zgodzie z niską korelacją między przepuszczalnością a porowatością efektywną i gęstością objętościową (odpowiednie wartości $\mathrm{r}=0,21 \mathrm{i}-0,20$ ). 
Tabela 4. Współczynniki korelacji wzajemnej między parametrami uzyskanymi z porozymetrii rtęciowej; pełny zbiór danych - kolor czarny, mikrofacja (3) utworów ziarnozwięzłych - kolor niebieski, mikrofacja (2) utworów mułozwięzłych - kolor czerwony

Table 4. Cross-correlation coefficients between parameters determined from mercury porosimetry; total data set - black colour, grainstones microfacies (3) - blue colour, mudstones microfacies (2) - red colour

\begin{tabular}{|c|c|c|c|c|c|c|c|c|c|}
\hline & $\rho b$ & Фef & $\begin{array}{l}\text { k_sr } \\
{[\mathrm{mm}]}\end{array}$ & $\begin{array}{c}\text { pow. wł. } \\
{\left[\mathrm{m}^{2} / \mathrm{g}\right]}\end{array}$ & $\mathrm{k} \_\mathrm{p}[\mathrm{mm}]$ & r_ $0,1 \mathrm{~mm}$ & $\begin{array}{c}\text { Фdyn.g } \\
{[\%]}\end{array}$ & r_ $1,0 \mathrm{~mm}$ & $\begin{array}{c}\text { Фdyn.r } \\
{[\%]}\end{array}$ \\
\hline \multirow{3}{*}{$\rho b$} & 1 & $-0,87$ & $-0,34$ & 0,22 & $-0,37$ & $-0,48$ & $-0,97$ & $-0,50$ & $-0,78$ \\
\hline & 1 & $-0,85$ & $-0,33$ & 0,10 & $-0,30$ & $-0,42$ & $-0,85$ & $-0,52$ & $-0,75$ \\
\hline & 1 & $-0,82$ & $-0,39$ & 0,27 & $-0,32$ & $-0,48$ & $-0,83$ & $-0,55$ & $-0,79$ \\
\hline \multirow{3}{*}{ Фef } & $-0,87$ & 1 & 0,33 & 0,34 & $-0,19$ & 0,50 & 0,99 & 0,42 & 0,81 \\
\hline & $-0,85$ & 1 & 0,32 & $-0,17$ & 0,29 & 0,47 & 0,99 & 0,46 & 0,78 \\
\hline & $-0,82$ & 1 & 0,41 & $-0,20$ & 0,27 & 0,47 & 0,97 & 0,43 & 0,87 \\
\hline \multirow{3}{*}{$\begin{array}{c}\text { k_sr } \\
{[\mathrm{mm}]}\end{array}$} & $-0,34$ & 0,33 & 1 & $-0,29$ & 0,48 & 0,23 & 0,34 & 0,46 & 0,50 \\
\hline & $-0,33$ & 0,32 & 1 & $-0,30$ & 0,46 & 0,19 & 0,33 & 0,45 & 0,49 \\
\hline & $-0,39$ & 0,41 & 1 & $-0,31$ & 0,76 & 0,37 & 0,46 & 0,52 & 0,45 \\
\hline \multirow{3}{*}{$\begin{array}{c}\text { pow. wł. } \\
{\left[\mathrm{m}^{2} / \mathrm{g}\right]}\end{array}$} & 0,22 & $-0,19$ & $-0,29$ & 1 & $-0,25$ & $-0,72$ & $-0,30$ & $-0,50$ & $-0,34$ \\
\hline & 0,18 & $-0,17$ & $-0,30$ & 1 & $-0,24$ & $-0,68$ & $-0,27$ & $-0,46$ & $-0,33$ \\
\hline & 0,26 & $-0,20$ & $-0,31$ & 1 & $-0,38$ & $-0,78$ & $-0,42$ & $-0,62$ & $-0,43$ \\
\hline \multirow{3}{*}{$\mathrm{k} \_\mathrm{p}[\mathrm{mm}]$} & $-0,19$ & 0,34 & 0,48 & $-0,25$ & 1 & 0,25 & 0,34 & 0,50 & 0,48 \\
\hline & $-0,32$ & 0,29 & 0,46 & $-0,24$ & 1 & 0,19 & 0,28 & 0,49 & 0,44 \\
\hline & $-0,32$ & 0,27 & 0,76 & $-0,38$ & 1 & 0,44 & 0,35 & 0,60 & 0,46 \\
\hline \multirow{3}{*}{$\begin{array}{c}\text { pory } \\
>0,1 \mathrm{~mm}\end{array}$} & $-0,48$ & 0,50 & 0,23 & $-0,72$ & 0,25 & 1 & 0,59 & 0,42 & 0,41 \\
\hline & $-0,42$ & 0,47 & 0,19 & $-0,68$ & 0,19 & 1 & 0,56 & 0,35 & 0,35 \\
\hline & $-0,48$ & 0,47 & 0,37 & $-0,78$ & 0,44 & 1 & 0,65 & 0,67 & 0,58 \\
\hline \multirow{3}{*}{$\begin{array}{c}\text { Фdyn.g } \\
{[\%]}\end{array}$} & $-0,97$ & 0,99 & 0,34 & $-0,30$ & 0,34 & 0,59 & 1 & 0,45 & 0,81 \\
\hline & $-0,85$ & 0,99 & 0,33 & $-0,27$ & 0,28 & 0,56 & 1 & 0,48 & 0,78 \\
\hline & $-0,83$ & 0,97 & 0,46 & $-0,42$ & 0,35 & 0,65 & 1 & 0,57 & 0,91 \\
\hline \multirow{3}{*}{$\begin{array}{c}\text { pory } \\
>1 \mathrm{~mm}\end{array}$} & $-0,50$ & 0,42 & 0,46 & $-0,50$ & 0,50 & 0,42 & 0,45 & 1 & 0,78 \\
\hline & $-0,52$ & 0,46 & 0,45 & $-0,46$ & 0,49 & 0,35 & 0,48 & 1 & 0,82 \\
\hline & $-0,55$ & 0,43 & 0,52 & $-0,62$ & 0,60 & 0,67 & 0,57 & 1 & 0,74 \\
\hline \multirow{3}{*}{$\begin{array}{c}\text { Фdyn.r } \\
{[\%]}\end{array}$} & $-0,78$ & 0,81 & 0,50 & $-0,34$ & 0,48 & 0,41 & 0,81 & 0,78 & 1 \\
\hline & $-0,75$ & 0,78 & 0,49 & $-0,33$ & 0,44 & 0,35 & 0,78 & 0,82 & 1 \\
\hline & $-0,79$ & 0,87 & 0,55 & $-0,43$ & 0,46 & 0,58 & 0,91 & 0,74 & 1 \\
\hline
\end{tabular}

Wybrane zależności korelacyjne (porowatość dynamiczna dla gazu vs. porowatość efektywna $(r=0,99)$ i porowatość dynamiczna dla ropy vs. porowatość efektywna $(r=0,81))$ zilustrowano na wykresach rozrzutu (rys. 4), gdzie odrębnie zaznaczono dane pochodzące z różnych otworów. Pojedyncze wartości z otworu Grotów-2 i Santok-1 można potraktować jako odstające (rys. 4a). Pozostałe wartości są zgromadzone wzdłuż przekątnej wykresu. 
Tabela 5. Współczynniki korelacji wzajemnej między parametrami uzyskanymi z porozymetrii helowej, pełny zbiór danych

Table 5. Cross-correlation coefficients between parameters determined from helium porosimetry, total data set

\begin{tabular}{|l|c|c|c|c|}
\hline & $\rho b\left[\mathrm{~g} / \mathrm{cm}^{3}\right]$ & Фef $[\%]$ & $\mathrm{K}[\mathrm{mD}]$ & $\operatorname{logK}$ \\
\hline$\rho \mathrm{b}\left[\mathrm{g} / \mathrm{cm}^{3}\right]$ & 1 & $-0,95$ & $-0,20$ & $-0,66$ \\
\hline$\Phi e f[\%]$ & $-0,95$ & 1 & 0,21 & 0,69 \\
\hline $\mathrm{K}[\mathrm{mD}]$ & $-0,20$ & 0,21 & 1 & 0,35 \\
\hline $\log \mathrm{K}$ & $-0,66$ & 0,69 & 0,35 & 1 \\
\hline
\end{tabular}

Zależność porowatości dynamicznej dla ropy w funkcji porowatości efektywnej (rys. 4b) pokazała większy rozrzut danych. W tym przypadku, jako odstające można uznać dane z otworu Santok-1 oraz Grotów-2 i Lubiatów-4. Wysoką odwrotną korelację zanotowano między procentowym udziałem porów o średnicach większych od $0,1 \mathrm{~mm}$ a powierzchnią właściwą $(\mathrm{r}=-0,72)$. Fakt ten potwierdza obniżający wpływ zailenia na porowatość i przepuszczalność, także w utworach węglanowych. Wysoka korelacja między porowatością dynamiczną dla gazu i ropy $(\mathrm{r}=0,81)$ potwierdza intuicyjny wniosek, że przestrzeń
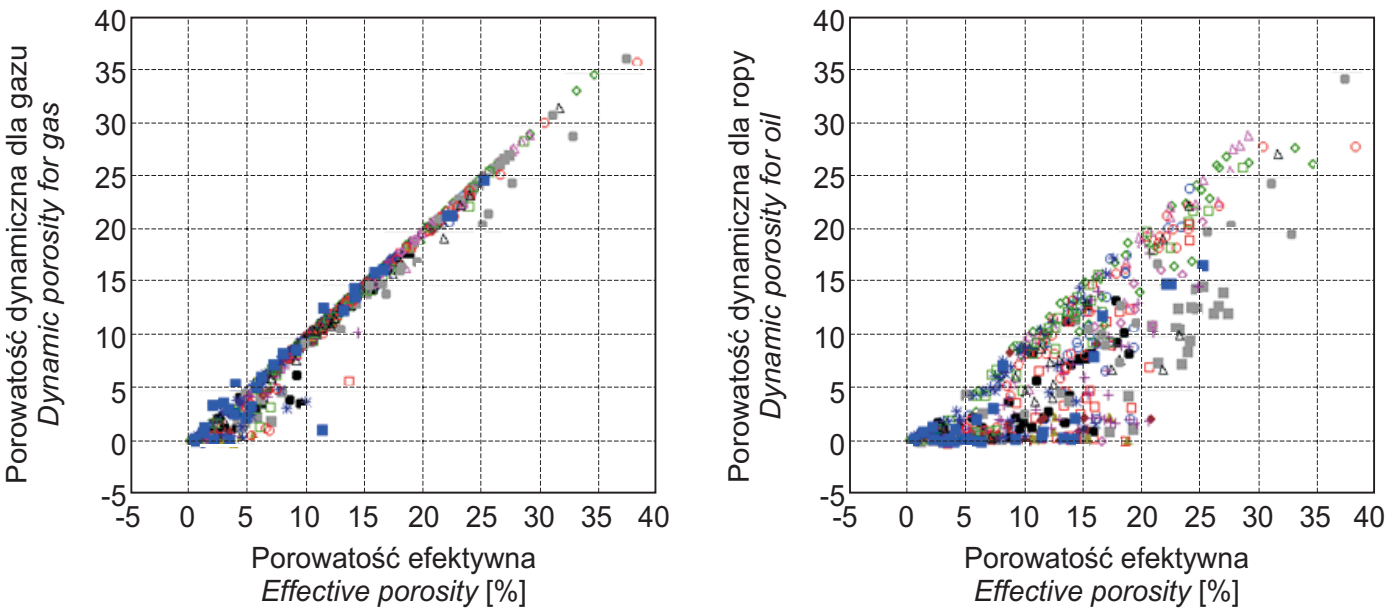

\begin{tabular}{|c|c|c|c|}
\hline $\begin{array}{l}\circ \text { Grotów-1 } \\
\square \text { Grotów-2 } \\
\diamond \text { Lubiatów-1 } \\
\Delta \text { Lubiatów-2 }\end{array}$ & $\begin{array}{l}\text { Lubiatów-4 } \\
\text { Międzychód-4 } \\
\text { Międzychód-5 } \\
\text { Międzychód-6 }\end{array}$ & $\begin{array}{l}\text { + Sieraków-1 } \\
\text { * Sowia Góra-1 } \\
\text { - Sowia Góra-2k } \\
\text { - Sowia Góra-4 }\end{array}$ & $\begin{array}{l}\diamond \text { Ciecierzyce-1K } \\
\Delta \text { Dzierżów-1K } \\
\text { Dzierżów-1K bis } \\
\text { Santok-1 }\end{array}$ \\
\hline
\end{tabular}

Rys. 4. Wykres rozrzutu porowatości dynamicznej dla gazu vs porowatość efektywna oraz porowatości dynamicznej dla ropy vs. porowatość efektywna; dolomit główny, porozymetria rtęciowa

Fig. 4. Scatterplot of dynamic porosity for gas vs. effective porosity and dynamic porosity for oil vs. effective porosity, the Main Dolomite, mercury porosimetry 
porowa otwarta dla ruchu ropy jest także drogą ruchu gazu. Stosunkowo niskie współczynniki korelacji między porowatością efektywną a procentowym udziałem porów o średnicach większych od $0.1 \mathrm{~mm}(\mathrm{r}=0,5)$ oraz o średnicach większych od $1 \mathrm{~mm}(\mathrm{r}=0,42)$, przy równocześnie wysokich współczynnikach korelacji między porowatością efektywną a porowatością dynamiczną dla gazu $(\mathrm{r}=0,99)$ i ropy $(\mathrm{r}=0,81)$ świadczą o obecności szczelin i ich wpływie na ruch mediów porowych.

W tabeli 4 zestawiono także współczynniki korelacji dla podzbiorów danych obejmujących mikrofację (3) utworów ziarnozwięzłych oraz mikrofację (2) utworów mułozwięzłych. Współczynniki korelacji w tych grupach zachowują się podobnie, co do znaku i wartości, jak dla pełnego zbioru danych. Taki wynik potwierdza jednorodność dolomitu w sensie ogólnym, przy zachowaniu zróżnicowania niektórych własności w podgrupach charakteryzujących mikrofacje. Na przykład wzrostowi średniej kapilary utworów ziarnozwięzłych towarzyszy wzrost średnicy progowej $(\mathrm{r}=0,46)$, a w takim samym przypadku w utworach mułozwięzłych współczynnik korelacji wynosi 0,76 . Wzrost średniej kapilary w mikrofacji (3) skorelowany był z procentowym udziałem porów o średnicach powyżej $1 \mu \mathrm{m}(\mathrm{r}=0,45)$, a także z porowatością dynamiczną dla ropy $(\mathrm{r}=0,49)$. Podobne związki korelacyjne dotyczyły także utworów mułozwięzłych, gdzie dodatkowo wzrostowi średniej kapilary towarzyszył wzrost porowatości efektywnej $(r=0,41)$. Średnica progowa utworów ziarnozwięzłych tworzyła także umiarkowane związki z porowatością dynamiczną dla ropy $(\mathrm{r}=0,44)$, a także udziałem porów o średnicach powyżej $1 \mu \mathrm{m}(\mathrm{r}=0,49)$. W przypadku utworów mułozwięzłych sytuacja jest podobna. W niektórych przypadkach współczynniki korelacji między parametrami utworów mułozwięzłych są wyraźnie wyższe w porównaniu z odpowiednimi wielkościami dla całego zbioru i utworów ziarnozwięzłych, np. przy korelacji powierzchni właściwej i procentowego udziału porów o średnicach większych od $0,1 \mu \mathrm{m}$. Taki wynik wskazuje na wpływ zailenia oraz bardzo drobnoziarnistej frakcji mineralnej na badany związek.

\section{Charakterystyka parametrów w strefach paleogenicznych}

Wykonano podział danych ze względu na strefy paleogeniczne związane z procesami sedymentacyjnymi. Obliczono podstawowe statystyki parametrów wyznaczonych na podstawie badań porozymetrii rtęciowej (tab. 6).

Zaobserwowano niewielkie zróżnicowanie niektórych parametrów. Charakterystyki gęstości objętościowej są bardzo podobne, mieszczą się w zbliżonych zakresach. Średnia arytmetyczna jest nieco wyższa jedynie dla strefy bariery węglanowej. Podobne stwierdzenie przedstawiono dla porowatości efektywnej oraz procentowego udziału porów o średnicach większych niż $0,1 \mathrm{~mm}$ i porowatości dynamicznej dla gazu. W strefie bariery węglanowej, w przypadku średniej kapilary i średnicy progowej, zauważono występowanie maksymalnych wartości odbiegających znacznie od odpowiednich liczb charakteryzujących strefy równi platformowej i podnóża platformy. W przypadku wymienionych wielkości zastosowano 
obliczenie średniej harmonicznej w celu wyeliminowania wartości skrajnych. Wymienione wielkości różnicują badane skały w odmiennych środowiskach sedymentacyjnych. W strefie podnóża platformy zaobserwowano najwyższe wartości procentowego udziału porów o średnicach większych niż $1 \mu \mathrm{m}$ oraz porowatości dynamicznej dla ropy, co skutkowało najwyższymi wartościami średnich wymienionych parametrów. Najwyższe wartości tych parametrów występowały w otworach Lubiatów-1 i -2. Średnie harmoniczne obliczone dla średniej kapilary i średnicy progowej w tej strefie także przybrały wartości najwyższe, mimo iż wartości maksymalne nie były największe.

Tabela 6. Podstawowe statystyki parametrów wyznaczonych na podstawie badań porozymetrii rtęciowej dla danych dolomitu głównego z różnych strefach paleogenicznych

Table 6. Basic statistics of parameters determined from the mercury porosimetry of the Main Dolomite in the different paleogenic zones

\begin{tabular}{|c|c|c|c|c|c|c|c|c|c|c|}
\hline \multicolumn{2}{|c|}{ Liczba próbek/strefa } & $\begin{array}{c}\rho b \\
{\left[\mathrm{~g} / \mathrm{cm}^{3}\right]}\end{array}$ & Фef [\%] & $\begin{array}{l}\text { k_sr } \\
{[\mu \mathrm{m}]}\end{array}$ & $\begin{array}{c}\mathrm{Sp} \\
{[\mathrm{m} 2 / \mathrm{g}]}\end{array}$ & $\begin{array}{c}\mathrm{k} \_\mathrm{p} \\
{[\mu \mathrm{m}]}\end{array}$ & $\begin{array}{c}\text { r_0,1 } \\
{[\%]}\end{array}$ & $\begin{array}{c}\text { Фdyn.g } \\
{[\%]}\end{array}$ & $\frac{r_{-} 1,0}{[\%]}$ & $\begin{array}{c}\text { Фdyn.r } \\
{[\%]}\end{array}$ \\
\hline \multirow{3}{*}{$\begin{array}{l}\text { 166/równi } \\
\text { platformowej }\end{array}$} & $\min$ & 2,19 & 8,49 & 0,31 & 0,37 & 2,23 & 82,25 & 8,02 & 23,83 & 3,97 \\
\hline & $\max$ & 2,54 & 20,15 & 1,02 & 0,80 & 7,56 & 97,33 & 19,66 & 58,44 & 12,68 \\
\hline & śred. & 2,39 & 13,94 & 0,56 & 0,59 & 4,12 & 91,28 & 13,42 & 40,46 & 6,53 \\
\hline \multirow{3}{*}{$\begin{array}{l}\text { 114/bariery } \\
\text { węglanowej }\end{array}$} & $\min$. & 2,20 & 8,41 & 0,53 & 0,53 & 0,77 & 69,41 & 7,08 & 17,26 & 0,70 \\
\hline & $\max$ & 2,60 & 21,54 & 11,15 & 1,03 & 27,86 & 95,81 & 19,78 & 68,06 & 14,60 \\
\hline & śred. & 2,41 & 14,00 & 0,59 & 0,70 & 2,37 & 85,64 & 12,91 & 28,94 & 2,05 \\
\hline \multirow{3}{*}{$\begin{array}{c}\text { 263/podnóża } \\
\text { platformy }\end{array}$} & $\min$ & 2,26 & 8,82 & 0,53 & 0,23 & 3,43 & 83,05 & 8,27 & 47,50 & 4,64 \\
\hline & $\max$ & 2,49 & 16,90 & 2,69 & 0,74 & 20,72 & 99,56 & 16,81 & 84,58 & 14,72 \\
\hline & śred. & 2,39 & 12,77 & 1,26 & 0,43 & 8,13 & 89,99 & 12,20 & 66,30 & 9,88 \\
\hline
\end{tabular}

Pogrubioną czcionką zaznaczono wartość średniej harmonicznej.

\section{Wnioski}

Wyniki badań laboratoryjnych porozymetrii rtęciowej rozszerzają znacznie informację o skale zbiornikowej (dolomicie głównym).

$\mathrm{Na}$ podstawie przeprowadzonej analizy statystycznej porównano parametry petrofizyczne trzech mikrofacji i stwierdzono, że utwory ziarnozwięzłe charakteryzowały się najlepszymi właściwościami zbiornikowymi. Dla tych utworów stwierdzono wysoką średnią porowatość efektywną oraz wysoką średnią porowatość dynamiczną dla gazu i ropy. Utwory te charakteryzowały się także wysoką przepuszczalnością. 
Stwierdzono duży procentowy udział próbek mikrofacji (3) w badanej populacji próbek dolomitu głównego. Próbki tej mikrofacji stanowiły $75 \%$ (w badaniach porozymetrii rtęciowej) i 72\% (w badaniach porozymetrii helowej) całej populacji. Taki wniosek jest korzystny z punktu widzenia dalszych prac poszukiwawczych w dolomicie głównym, gdyż pozwala założyć, że $72-75 \%$ przewierconego dolomitu głównego należy do mikrofacji (3) utworów ziarnozwięzłych. Stwierdzono także, że różnica między wartościami parametrów wyznaczonymi dla całej grupy danych i zbioru próbek mikrofacji (3) nie jest duża. Można zatem przyjać, że badania parametrów na całym zbiorze danych są reprezentatywne w zakresie własności zbiornikowych dla próbek należących do mikrofacji utworów ziarnozwięzłych.

Badania przeprowadzone $\mathrm{w}$ grupach danych pochodzących $\mathrm{z}$ otworów odwierconych w różnych strefach paleogenicznych, związanych ze środowiskiem sedymentacji, pozwoliły stwierdzić, że w strefie bariery węglanowej wybrane parametry przyjmują wartości wyraźnie różniące się od odpowiednich liczb w strefach równi platformowej i podnóża platformy.

Wykonana analiza statystyczna poszerzyła informację o parametrach zbiornikowych skał i ułatwiła ich szybką klasyfikację pod względem stref sedymentacyjnych na obszarze platformy oraz ocenę mikrofacji utworów ziarnozwięzłych o najlepszych własnościach do gromadzenia i oddawania węglowodorów w dolomicie głównym.

Wyniki stanowiqce podstawe artykułu uzyskano w ramach projektów badawczych: Grant KBN nr 4 T12B 0427 i nr N N525 348538, NCN Kraków prowadzonych przez dr. inż. Romana Semyrke w latach 2004-2007 i 2010-2012

\section{Spis symboli}

$\rho b\left[\mathrm{~g} / \mathrm{cm}^{3}\right]$ - gęstość objętościowa,

$\rho \mathrm{m}\left[\mathrm{g} / \mathrm{cm}^{3}\right]$ - gęstość szkieletowa,

Фef [\%] - porowatość efektywna,

Фdyn.g [\%] - porowatość dynamiczna dla gazu,

Фdyn.r [\%] - porowatość dynamiczna dla ropy,

$\mathrm{K}[\mathrm{mD}]-$ przepuszczalność fizyczna,

$\mathrm{Sp}\left[\mathrm{m}^{2} / \mathrm{g}\right] \quad-$ powierzchnia właściwa,

r_0,1 [\%] - procentowy udział porów o średnicach większych od $0,1 \mu \mathrm{m}$,

r_1,0 [\%] - procentowy udział porów o średnicach większych od $1 \mu \mathrm{m}$,

k_sr $[\mu \mathrm{m}]$ - średnia kapilara,

$\mathrm{k} \_\mathrm{p}[\mu \mathrm{m}]$ - średnica progowa,

$\min \quad-$ wartość minimalna,

$\max \quad-$ wartość maksymalna,

śred. - - wartość średnia,

med. $\quad-$ mediana, 
d kw - kwartyl dolny,

g kw - kwartyl górny,

p $10-$ percentyl $10 \%$,

p 90 - percentyl 90\%,

war. - wariancja,

od. st. - odchylenie standardowe,

sk. $\quad-$ skośność,

kurt. $\quad-$ kurtoza,

r $\quad-$ współczynnik korelacji.

\section{LITERATURA}

Czekański i in. 2010 - Czekański, E., Kwolek, K. i Mikołajewski, Z. 2010. Złoża węglowodorów w utworach cechsztyńskiego dolomitu głównego (Ca2) na bloku Gorzowa. Przeglad Geologiczny t. 58, s. 695-703.

Bachleda-Curuś, T. i Semyrka, R. 1997. Zastosowanie analizy porozymetrycznej dla oceny przestrzeni porowej skał w profilach utworów karbonu dolnego i kambru środkowego północno-zachodniej Polski. Geologia t. 23, z. 2, s. 155-187.

Burzewski i in. 2001 - Burzewski, W., Semyrka, R. i Słupczyński, K. 2001. Kwalifikacja naftowa przestrzeni porowej skał zbiornikowych. Polish Journal of Mineral Resources, Geosynoptics Society GEOS t. 3, s. $185-191$.

Jaworowski, K. i Mikołajewski, Z. 2007. Oil and gas bearing sediments of the Main Dolomite (Ca2) in the Międzychód region: a depositional model and the problem of the boundary between the second and third depositional sequences in the Polish Zechstein Basin. Przeglad Geologiczny t. 55, s. 1017-1024.

Kotarba, M. i Wagner, R. 2007. Generation potential of the Zechstein Main Dolomite (Ca2) carbonates in the Gorzów Wielkopolski-Międzychód-Lubiatów area: geological and geochemical approach to microbial-alg source rock. Przeglad Geologiczny t. 55, s. 1025-1037.

Mikołajewski, Z. i Buniak, A. 2007. Petrologiczna charakterystyka dolomitu głównego w rejonie Międzychodu. Raport projektu KBN nr 4 T12B 0427, kierowanego przez dr R. Semyrkę (2004-2007).

Mikołajewski, Z. i Buniak, A. 2011. Petrologiczna charakterystyka dolomitu głównego w rejonie Gorzów-Pniewy. Raport projektu NN 525348 538, kierowanego przez dr R. Semyrkę (2010-2012).

Semyrka, R. 2007. Charakterystyka zmienności parametrów petrofizycznych dolomitu głównego $w$ rejonie Międzychodu. Praca pod kier. R. Semyrki. Grant KBN nr 4 T12B 0427, Warszawa.

Semyrka, R., Semyrka, G. i Zych, I. 2008. Zmienność parametrów petrofizycznych subfacji dolomitu głównego zachodniej strefy półwyspu Grotowa w świetle badań porozymetrycznych. Geologia t. 34, z. 3, s. 445-468.

Semyrka, R. 2012. Facjalno-strukturalne uwarunkowania akumulacji węglowodorów dolomitu głównego (Ca2) w granicznej strefie platformy węglanowej w obszarze Gorzów-Pniewy. Grant badawczy pod kierownictwem dr inż. R. Semyrki. Grant Nr N N525 348538, NCN Kraków.

Semyrka, R. 2013. Jakościowa i ilościowa charakterystyka petrofizyczna subfacji dolomitu głównego w strefach paleogeograficznych. Gospodarka Surowcami Mineralnymi-Mineral Resources Management t. 29, z. 3, s. 99-115. 


\title{
ANALIZA STATYSTYCZNA PARAMETRÓW MIKROFACJI DOLOMITU GEÓWNEGO W GRANICZNEJ STREFIE PLATFORMY WĘGLANOWEJ
}

\author{
Słowa kluczowe
}

dolomit główny, platforma węglanowa, środowiska depozycyjne, mikrofacje,

Gorzów, Grotów, Krobielewko

\section{Streszczenie}

Duża liczba wyników badań laboratoryjnych parametrów zbiornikowych dolomitu głównego na obszarze platformy węglanowej, w rejonie wschodniej części platformy Gorzowa, w zatoce Noteci wraz z mikroplatformą Krobielewka, na półwyspie Grotowa, oraz na fragmencie platformy wielkopolskiej, sięgającym rejonu Pniew umożliwiła wykonanie wiarygodnych analiz statystycznych. Standardowe badania na próbkach skał (gęstości objętościowej, porowatości efektywnej i przepuszczalności fizycznej) wzbogacone zostały o wyniki pomiarów porozymetrii rtęciowej. Wyniki badań laboratoryjnych, przede wszystkim porozymetrii rtęciowej, rozszerzyły znacznie informację o skale zbiornikowej (dolomicie głównym) i przyczyniły się do wydzielenia różnorodnych mikrofacji oraz stref paleogeograficznych.

Na podstawie wyników przeprowadzonej analizy statystycznej porównano parametry petrofizyczne trzech mikrofacji i stwierdzono, że utwory ziarnozwięzłe charakteryzowały się najlepszymi właściwościami zbiornikowymi. Dla tych utworów stwierdzono wysoką średnią porowatość efektywną oraz wysoką średnią porowatość dynamiczną dla gazu i ropy. Utwory te charakteryzowały się także wysoką przepuszczalnością.

Stwierdzono duży procentowy udział próbek mikrofacji utworów ziarnozwięzłych w badanej populacji próbek dolomitu głównego. Próbki tej mikrofacji stanowiły 75\% (w badaniach porozymetrii rtęciowej) i 72\% (w badaniach porozymetrii helowej) całej populacji. Taki wniosek jest korzystny z punktu widzenia dalszych prac poszukiwawczych w dolomicie głównym, gdyż pozwala założyć, że $72-75 \%$ przewierconego dolomitu głównego należy do mikrofacji utworów ziarnozwięzłych. Stwierdzono także, że różnica między wartościami parametrów wyznaczonymi dla całej grupy danych i zbioru próbek mikrofacji utworów ziarnozwięzłych nie jest duża. Można zatem przyjąć, że badania parametrów w całym zbiorze danych są reprezentatywne w zakresie właściwości zbiornikowych dla próbek należących do mikrofacji utworów ziarnozwięzłych.

Badania przeprowadzone $\mathrm{w}$ grupach danych pochodzących $\mathrm{z}$ otworów odwierconych w różnych strefach paleogenicznych, związanych ze środowiskiem sedymentacji, pozwoliły stwierdzić, że w strefie bariery węglanowej wybrane parametry przyjmują wartości wyraźnie różniące się od odpowiednich danych w strefach równi platformowej i podnóża platformy.

Wykonana analiza statystyczna poszerzyła informację o parametrach zbiornikowych skał i ułatwiła ich szybką klasyfikację pod względem stref sedymentacyjnych na obszarze platformy oraz ocenę mikrofacji utworów ziarnozwięzłych o najlepszych właściwościach do gromadzenia i oddawania węglowodorów w dolomicie głównym. 


\title{
STATISTICAL ANALYSIS OF THE MAIN DOLOMITE MICROFACIES PARAMETERS IN THE BOUNDARY ZONE OF CARBONATE PLATFORM
}

\author{
Key words \\ the Main Dolomite, carbonate platform, depositional environment, microfacies, \\ Gorzów, Grotów, Krobielewko
}

\begin{abstract}
Reliable statistical analysis was carried out for the Main Dolomite reservoir parameters on the area of carbonate platform in the vicinity of the east part of Gorzów Platform, in the Noteć Bay, together with Krobielewko Microplatform, on the Grotów Peninsula and on the part of Wielkopolska Platform, reaching Pniewy region thanks to large number of laboratory measurements results. The standard measurements on the core samples (bulk density, effective porosity and absolute permeability) were enriched by mercury porosimetry results. Laboratory measurements results, especially mercury porosimetry, extended considerably information about the reservoir rock (the Main Dolomite) and contributed to the separation of diverse microfacies and paleogeographic zones.

Petrophysical parameters of the three microfacies were compared based on the results of statistical analysis. It was found that grainstones were characterized by the best reservoir parameters. For these microfacies high average effective porosity and average dynamic porosity for oil and gas were discovered. Additionally, grainstones characterized by high permeability.

High percentage of grainstones microfacies samples was detected in the analyzed population of the Main Dolomite. Grainstones samples constituted 75\% (in the mercury porosimetry) and $72 \%$ (in the helium porosimetry) of the total population. Such a conclusion was advantageous from the viewpoint of further exploration works in the Main Dolomite, as it allowed assume that $72-75 \%$ of the drilled Main Dolomite belongs to the grainstones microfacies. It was also found that the difference between the values of the parameters determined for the entire group of data and a set of grainstones samples was not large. Therefore, it could be assumed that the parameters analysis on the entire set of data were representative in terms of reservoir properties for the samples belonging to the grainstones microfacies.

Studies carried out in the groups of data from the wells drilled in the different paleogenic zones, connected with sedimentation environment, revealed that selected parameters from the carbonate barrier significantly differed from the corresponding values in the platform plain and platform slope.

Statistical analysis expanded the information about reservoir parameters of the rocks and facilitated their rapid classification in terms of sedimentation zones in the area of the platform and grainstones evaluation with the best properties for the accumulation and migration of hydrocarbons in the Main Dolomite.
\end{abstract}

